\title{
miR-205 is involved in metastatic potential of 21T series, a breast cancer progression model
}

\author{
Luiza Stankevicins ${ }^{1,2^{*}}$, Ana Barat ${ }^{2}$, Yegor Vassetzky², Claudia Vitória de Moura Gallo ${ }^{1}$ \\ From São Paulo Advanced School of Comparative Oncology \\ Águas de São Pedro, Brazil. 30 September - 6 October 2012
}

\section{Background}

microRNA (miRNA) is a class of non-coding RNAs, which regulate gene expression at the post-transcriptional level. Many miRNAs have been implicated in several human cancers, as these regulatory molecules play important roles in key cellular processes, including cell proliferation, differentiation and response to DNA damage.

\section{Methods}

To gain insights into the mechanisms involved in breast cancer initiation and progression we conducted a miRNA global expression on 21T series. These cell lines represent an in vitro model of breast cancer progression comprising immortalized cell lines derived from the same patient diagnosed with Her-2 overexpressing ductal carcinoma. The set include a normal epithelia $(16 \mathrm{~N})$, primary in situ ductal carcinoma (21PT and 21NT) and cells derived from pleural effusion of lung metastasis (21MT-1 and 21MT-2). To confirm microarray results, the expression of the most significantly altered miRNAs were checked by qPCR. Matrigel invasion assay was done to evaluate the migration capacity of 21 Tcells and Her-2, ZEB-1 and e-cadherin protein levels were achieved by western blot.

\section{Results}

Analysis of $21 \mathrm{~T}$ series revealed a significant downregulation of miR-205 together with an enrichment of its predicted target, the pro-metastatic factor $Z E B-1$ and the consequent reduction of e-cadherin levels in the invasive 21MT cells.

\section{Conclusions}

These molecular alterations, in special the downregulation of miR-205 in cancer cells, can participate on modulation of epithelial to mesenchymal transition and increase the metastatic potential on breast cancer.

\section{Financial support}

Faperj, CAPES, CNPq and Université Paris XI.

\section{Author details}

'Departamento de Genética, Universidade do Estado do Rio de Janeiro, Instituto de Biologia Roberto Alcantara Gomes, Rio de Janeiro, Brazil. ${ }^{2}$ Université Paris-Sud 11 CNRS UMR 8126 «Signalisation, noyaux et innovations en cancérologie», Institut de Cancérologie Gustave-Roussy, Université Paris-Sud 11, Villejuif, France.

Published: 4 April 2013

doi:10.1186/1753-6561-7-S2-P44

Cite this article as: Stankevicins et al:: miR-205 is involved in metastatic potential of $21 \mathrm{~T}$ series, a breast cancer progression model. BMC Proceedings 2013 7(Suppl 2):P44.

\footnotetext{
* Correspondence: luiza.stank@gmail.com

'Departamento de Genética, Universidade do Estado do Rio de Janeiro,

Instituto de Biologia Roberto Alcantara Gomes, Rio de Janeiro, Brazil

Full list of author information is available at the end of the article
}

Submit your next manuscript to BioMed Central and take full advantage of:

- Convenient online submission

- Thorough peer review

- No space constraints or color figure charges

- Immediate publication on acceptance

- Inclusion in PubMed, CAS, Scopus and Google Scholar

- Research which is freely available for redistribution 